\title{
Alzheimer Hastalığı ile İlişkilendirilen APH1A Genindeki Zararlı SNP’lerin In Silico Yöntemler ile Belirlenmesi
}

\section{Ebru ÖZKAN OKTAY*1 (D), Tuğba KAMAN ${ }^{2}$ (D), Ömer Faruk KARASAKAL ${ }^{3}$ (D), Korkut ULUCAN ${ }^{4}$ (D), Muhsin KONUK 5 (D), Nevzat TARHAN6 ${ }^{(D)}$}

\author{
1Üsküdar Üniversitesi, Sağlık Hizmetleri Meslek Yüksekokulu, Laboratuvar Teknolojisi Programı, 34664, İstanbul, \\ Türkiye \\ 2Üsküdar Üniversitesi, Sağlık Hizmetleri Meslek Yüksekokulu, Tıbbi ve Aromatik Bitkiler Programı, 34664, İstanbul, \\ Türkiye \\ 3Üsküdar Üniversitesi, Sağlık Hizmetleri Meslek Yüksekokulu, Tıbbi Laboratuvar Teknikleri Programı, 34664, İstanbul, \\ Türkiye \\ ${ }^{4}$ Marmara Üniversitesi, Diş Hekimliği Fakültesi, Temel Tıp Bilimleri, Tıbbi Biyoloji ve Genetik Bölümü, 34854, İstanbul, \\ Türkiye \\ 5Üsküdar Üniversitesi, Mühendislik ve Doğa Bilimleri Fakültesi, Moleküler Biyoloji ve Genetik Bölümü, 34662, İstanbul, \\ Türkiye \\ 6Üsküdar Üniversitesi, İnsan ve Toplum Bilimleri Fakültesi, Psikoloji Bölümü, İstanbul, 34662, Türkiye
}

(Alınış / Received: 05.02.2019, Kabul / Accepted: 19.07.2019, Online Yayınlanma / Published Online: 30.08.2019)

Anahtar Kelimeler APH1A,

Polimorfizm,

Alzheimer Hastalığı, In silico
Özet: Alzheimer hastalığı (AH), $\beta$-amiloid $(A \beta)$ senil plakların ve nörofibriler yumakların patolojik birikimi ile karakterize olan ilerleyici bir nörodejeneratif hastalıktır. $\gamma$-sekretaz, AH nedeni olan amiloid $\beta$ peptidi $(A \beta)$ üretmektedir. $\gamma$-sekretaz makromoleküler bir komplekstir ve APH1A geninin kodladığı protein bu komplekste yer almaktadır. Bu çalışmada, APH1A genindeki yanlış anlamlı (missense) tek nükleotid polimorfizmlerinin (SNP) proteinin yapısı ve stabilizasyonu üzerindeki olası zararlı etkilerinin in silico yöntemler kullanılarak belirlenmesi amaçlanmıştır. Zararlı SNP’lerin tahmin edilmesi için PolyPhen-2 ve SIFT yazılım araçları, protein stabilizasyonu değișimlerinin tespit edilmesi için I-Mutant 2.0 yazılımı, yabanıl ve mutant tip proteinlerin üç boyutlu modellemeleri için Project HOPE yazılım aracı kullanılmıştır. Sonuçlar, APH1A geninde yer alan toplam 3567 SNP'nin 257 tanesinin yanlış anlamlı SNP olduğunu göstermiştir. 257 SNP'nin in silico analizlerine göre, rs11548266, rs74126634, rs145324799, rs199961673, rs370361277, rs370719475 ve rs376071112 polimorfizmlerinin zararlı etkilerinin olabileceği belirlenmiștir. Çalıșmamızda gerçekleștirdiğimiz in silico analizler, Alzheimer hastalığı ile ilgili APH1A geninde yer alan 3567 SNP'nin tamamının genotiplenmesi yerine proteinin yapısı ve stabilizasyonuna zararlı etkisi olabilecek SNP'lerin genotiplenmesine ilişkin veri sağlamaktadır. Dolayısıyla, zararlı olduğu tespit edilen SNP'ler genotipleme çalışmalarının en önemli basamağı olan SNP seçiminde ve deney tasarımında kullanılabilecektir. $\mathrm{Bu}$ nedenle, elde ettiğimiz sonuçların Alzheimer hastalığı ile ilgili gelecekte yapılacak olan hem deneysel hem de in silico çalışmalara katkı sağlayacağı düşünülmektedir.

\section{Determination of Deleterious SNPs in APH1A Gene Related to Alzheimer's Disease by In Silico Methods}

\section{Keywords}

APH1A,

Polymorphism, Alzheimer's Disease, In silico

\begin{abstract}
Alzheimer's disease (AD) is a progressive neurodegenerative disease characterized by pathological accumulation of $\beta$-amyloid $(A \beta)$ senile plaques and neurofibrillary tangles. $\gamma$-secretase produces the amyloid $\beta$ peptide $(A \beta)$, which causes AD. $\gamma$-secretase is a macromolecular complex and the protein encoded by the APH1A gene is located in this complex. In this study, it was aimed to determine the possible deleterious effects of missense single nucleotide polymorphisms (SNPs) in APH1A gene on the protein structure and stabilization via in silico methods. PolyPhen-2 and SIFT were used to predict deleterious SNPs, I-Mutant 2.0 software was used to detect protein stabilization changes and Project HOPE software tool was used to make three-dimensional modeling of wild and mutant type proteins. The results showed that 257 SNPs among a total of 3567 SNPs in the APH1A gene were missense SNPs. According to the in silico analysis of the 257 SNPs it has been determined that rs11548266, rs74126634, rs145324799, rs199961673, rs370361277, rs370719475 and rs376071112 polymorphisms may have deleterious effects. The results of in silico analysis provide data for genotyping of SNPs which have deleterious effects on protein structure and stabilization rather than genotyping of entire 3567 SNPs in the APH1A gene associated with Alzheimer's disease. Therefore, deleterious SNPs may be used in the selection of SNPs and experimental design which are the most important stages of genotyping studies. Thus, we envisaged that the obtained results will contribute to the further studies either experimental or in silico on Alzheimer's disease.
\end{abstract}




\section{Giriş}

Alzheimer hastalı̆̆ $(\mathrm{AH}), \quad \beta$-amiloid $(\mathrm{A} \beta)$ senil plakların ve nörofibriler yumakların patolojik birikimi ile karakterize olan ilerleyici bir nörodejeneratif hastalıktır [1]. Alzheimer hastalığı erken başlangıçlı ailesel ve geç başlangıçlı sporadik olmak üzere ikiye ayrılmaktadır. AH olgularının çoğunluğu çevresel, genetik ve metabolik faktörleri içeren birçok etiyopatojenik mekanizmayı kapsayan geç başlangıçlı sporadik tipinde olduğu belirtilmektedir [1-2].

Aspartil proteaz üyesi olan $\gamma$-sekretazın enzimsel aktivitesi sonucu $\mathrm{AH}$ nedenlerinden olan amiloid $\beta$ peptidi $(A \beta)$ oluşur [3]. $\gamma$-sekretaz, hem normal fizyolojide hem de Alzheimer hastalığının (AH) patolojisindeki kritik rolü olması nedeniyle biyomedikal araștırmaların sınırında yer almaktadır. $\gamma$-sekretaz, intramembran proteaz olarak fonksiyonu olan ve yapısinda presenilin homodimer (PSEN1 ve PSEN2), nicastrin (NCSTN), anterior pharynx defective-1 (APH1A or APH1B) ve presenilin enhancer-2 (PSENEN)'yi içeren bir makromoleküler komplekstir [4-6]. Presenilin (PSEN), $\gamma$-sekretazın katalitik alt ünitesidir ve pek çok PSEN mutasyonu ailesel Alzhiemer hastalığı ile ilişkilendirilmiştir. PSEN'nin PSEN1 ve PSEN2 olmak üzere iki homoloğu, APH1'inde APH1a ve APH1b olmak üzere iki izoformu vardır [3].

APH1A geni (OMIM 607629) Notch reseptörü ve amiloid beta prekürsör protein (APP) gibi integral membran proteinlerini kesen gama sekretaz kompleksinin bir bileşenini kodlar (https://www.ncbi.nlm.nih.gov/gene/51107).

APH1A geni 1. kromozomun uzun kolunda yer alır (1q21.2) ve 265 amino asitlik bir proteini kodlar. APH1, yedi transmembran domaini ile $\sim 30 \mathrm{kDa}$ 'luk bir integral membran proteinidir. APH1, $\gamma$-sekretaz kompleksinin stabilitesi, aktivitesi ve seçiciliğinde rol oynamaktadır [6-8].

$\gamma$-sekretaz 90'dan fazla farklı subsratı keser bunların içinde APP ve Notch sırası ile AH ve kanserdeki rolleri nedeniyle en çok çalışılanlardandır [6,9]. APP'den A $\beta$ üretimi, $\beta$ - ve $\gamma$-sekretazları içeren iki aşamalı bir proteolitik işlem yoluyla gerçekleşir. Önce BACE1 ( $\beta$ site APP cleaving enzyme) membrana bağlanmış bir çözünebilir C-terminal fragmanını üretmek için APP'yi keser. Sonra $\gamma$-sekretaz aktivitesi ile Cterminal fragmanını keserek $A \beta 40$ ve $A \beta 42$ oluşmasını sağlar $[10,11]$. Oluşan her iki tip peptit de amiloid plaklarda bulunabilir, ancak A $\beta 42$ daha doğrudan nörotoksiktir ve agregasyon için daha büyük bir eğilime sahiptir $[10,12]$. Hücresel kompartımanlarda biriken nörotoksik $\mathrm{A} \beta$ mitokondriyal hasara, sinaptik hasara ve tau proteininin hiperfosforilasyonuna yol açarak hücresel fonksiyonlara zarar vermektedir $[10,13,14]$.

Tek nükleotid polimorfizmleri (SNP), insan genomundaki en yaygın varyasyon kaynakları arasındadır. Bazı durumlarda, SNP'lerin biyolojik etkisi bir veya daha fazla hastalığa yatkınlığı artırabilmektedir. Hastalığa yatkınlığı ve sonucunu etkileyen SNP'lerin tanımlanması, hasta ve kontrollerde SNP'lerin genotiplenmesi ve frekanslarında sistematik farklılıklar aranmasıyla sağlanmaktadır $[15,16]$. Hastalıklarla ilişkili SNP'leri belirleyebilmek için öncelikle in silico araçlar kullanarak SNP'lerin olası zararlı etkilerini belirlemek ve elde edilen bulgulara göre genotipleme çalışmalarını planlamak günümüzde tercih edilen yaklaşımlardan biridir. Yapılan literatür taramasına göre APH1A geninde yer alan yanlış anlamlı SNP'lerin zararlı etkileri in silico yöntemler kullanılarak araştırılmamıștır. Bununla birlikte, APH1A genindeki tek nükleotid polimorfizmleri ve Alzheimer hastalığ riski üzerine yapılan bazı genotipleme çalışmaları bulunmaktadır. 2003 yılında Poli ve ark. APH1A/B genlerinde yer alan altı polimorfizmin $\mathrm{AH}$ ile ilişskisini araştırmış ancak anlamlı bir sonuç bulunamadığını bildirmiştir [17]. Wang ve Jia (2009) ve Qin ve ark. (2011), APH-1A geninin promotor bölgesinde bulunan rs3754048 (-980C/G) polimorfizminin Alzheimer hastalığı riski ile ilişkili olduğunu bildirmiştir [18], [19]. 2015 yılında yapılan bir başka çalışmada, Yu ve ark. (2015) aralarında APH1A geninin de bulunduğu bazı genlerdeki, tek nükleotid polimorfizmlerinin şizofreni ile ilişkisini araştırmış ancak hasta ve kontrol grupları arasında istatistiksel olarak anlamlı bir fark olmadığını bildirmiştir [20]. Çinleti ve ark. (2015) Alzheimer hastalığı ile APH1A geninde yer alan rs3754048 (980C/G) polimorfizminin ilişkisini deneysel olarak araştırmış ancak istatistiksel olarak anlamlı bir sonuç elde etmediklerini bildirmişlerdir [21].

$\mathrm{Bu}$ çalışmanın amacı, $\mathrm{AH}$ ile ilişkilendirilen $A P H 1 A$ genindeki zararlı etkisi olabilecek SNP'lerin farklı bilgisayar tabanlı yazılım araçları aracılığı ile tahmin edilmesi, gen-gen ilişkilerinin belirlenmesi ve sonuçların yapılacak olan deneysel araştırmalara veri sağlamasıdır.

\section{Materyal ve Metot}

\subsection{Gen- gen ilișkilerinin belirlenmesi}

GeneMANIA, ilişkili genleri bulmak için, birçok kapsaml, kamuya açık biyolojik veri setlerini araştıran bir yazılım aracıdır. Araştırma parametreleri içerisinde protein-protein, proteinDNA ve genetik etkileşimleri, yolakları, reaksiyonları, gen-protein ekspresyon verileri, protein domainleri ve fenotipik tarama profilleri yer almaktadır. Aynı 
zamanda veriler literatüre bağlı olarak düzenli bir şekilde güncellenmektedir. GeneMANIA, elde ettiği verilerle oluşturduğu ağları birleștirmek için birkaç farklı yöntem kullanabilmektedir. $\mathrm{Bu}$ çalışmada kullanmış olduğu yöntem, otomatik olarak seçilen ölçme metodudur (http://genemania.org/).

\subsection{Veri Eldesi}

APH1A genindeki SNP'ler NCBI dbSNP veri tabanından 2018 yılı Mayıs ayında elde edilmiştir (https://www.ncbi.nlm.nih.gov/snp/). Bu SNP'lerden yanlış anlamlı olanlar (missense) ileri analizler için seçilmiştir. APH1A geninin kodladığı proteinin dizisi ve erişim numarası, NCBI dbSNP (https://www.ncbi.nlm.nih.gov/snp/) ve Uniprot veritabanlarından (http://www.uniprot.org/) elde edilmiştir.

\subsection{Zararlı SNP'lerin belirlenmesi}

Zararlı/hasar verici SNP’lerin belirlenmesi için çevrimiçi hizmet veren yazılım araçları kullanılmıştır. Bu amaçla Şekil 1'de gösterilen sıralama takip edilmiştir.

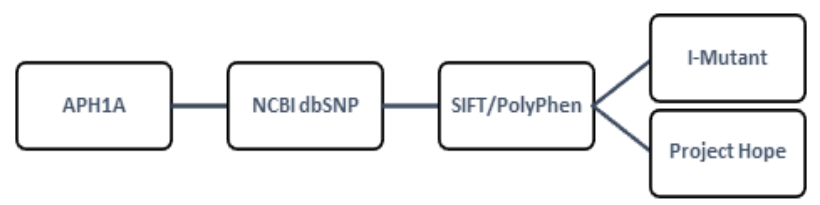

Şekil 1. SNP Analizlerinde Online Yazılım Araçlarının Kullanımı (Kaynak 20'den modifiye edilmiştir.)

SIFT (Sorting Intolerant From Tolerant) yazılım aracı bir amino asit substitüsyonunun protein fonksiyonunu etkileyip etkilemediğini dizi homolojisine ve amino asitlerin fiziksel özelliklerine dayanan bir yöntem ile tahmin etmektedir (http://siftdna.org/www/SIFT dbSNP.html). SIFT programındaki cutoff değeri $\geq 0.05$ bir tolerans indeksidir [22]. Amino asit substitüsyonunun $<0.05$ bir değere sahip olması vücuda zararlı/toleranssız olarak öngörülürken $>0,05$ bir değere sahip olması ise tolere edilebilir olduğu şeklinde öngörülmektedir $[23,24]$.

PolyPhen-2 (Polymorphism Phenotyping v2) yazılım aracl bir amino asit substitüsyonunun bir insan proteininin yapısı ve işlevi üzerindeki olası etkisini, doğrudan fiziksel ve karşılaştırmalı değerlendirmeler kullanarak tahmin eden bir araçtır (http://genetics.bwh.harvard.edu/pph2/). Tahmin sonuçları zarar verici ya da tehlikesiz şeklinde elde edilmektedir [24,25]. Bu yazılım aracı üç boyutlu yapısı bilinen bir protein ile substitüsyon bölgesinin karakterizasyonunu temel alarak bir skor hesaplaması yapmaktadır. PolyPhen skoru (PSIC skoru) her bir bölgedeki varyantlar ve bunların aralarındaki farklılıklar için hesaplanmaktadır.
Varyantlar arasındaki skor farklılığının yüksek olması, belirli bir amino asit substitüsyonunun fonksiyonel etkilerinin daha yüksek olabileceği anlamina gelmektedir [22].

Amino asit substitüsyonunun proteinin stabilizasyonu üzerine etkisini belirlemek için IMutant 2.0 yazılımı kullanılmıştır. I-Mutant 2.0, mutasyon nedeniyle meydana gelen protein stabilite değişimini, protein yapısından ya da protein dizisinden tahmin etmek üzere optimize edilmiş bir yazılımdır. I-Mutant 2.0, yabanıl ve mutant tip amino asitler arasındaki serbest enerji değişiminin (DDG) protein stabilizasyonu ile ilişkisini ortaya çıkarmaktadır. Hesaplanan DDG $<0$ (kcal/mol): stabilitedeki azalış, DDG $>0$ (kcal/mol): stabilitedeki artışı göstermektedir [22,26]. Sonuç olarak, protein stabilizasyonu azalmıştır ya da artmıştır şeklinde bir tahmin ortaya koymaktadır.

\subsection{Zararlı SNP'lerin Project HOPE ile Modellenmesi}

Project HOPE, üç boyutlu protein yapısı üzerindeki hesaplamaları, UniProt veritabanındaki dizi açıklamalarını ve Reprof yazılımındaki tahminleri de kapsayan bir seri kaynaktan yapisal bilgileri toplayan bir yazılım aracıdır. HOPE, protein yapısı üzerindeki belirli bir mutasyonun etkisini analiz etmek için bu bilgileri birleștirerek yabanıl ve mutant tip amino asitlerin, proteinin üç boyutlu yapısına etkilerinin, modellemeler aracılığıla tahmin edilmesine olanak sağlamaktadır

(http://www.cmbi.ru.nl/HOPE/method/).

\section{Bulgular}

\subsection{Gen-Gen Etkileșimleri}

Şekil 2'de APH1A'nın gen-gen etkileşim ağı verilmiştir. Gen-gen etkileşim sonuçlarına göre, APH1A geninin 20 gen ile ilişkisine bakıldığında, bu genler arasında toplam 333 bağlantı olduğu tespit edilmiştir (http://genemania.org/).

\subsection{PolyPhen-2 ve SIFT yazılımları tarafından zararlı olduğu tespit edilen SNP'ler}

NCBI dbSNP veri tabanı tarandığında APH1A geninde toplam 3567 SNP bulunduğu, bunlardan 257'sinin missense (yanlış anlamlı) SNP olduğu tespit edilmiştir. $\mathrm{Bu} 257$ missense SNP'den SIFT ve PolyPhen-2 yazılımlarının her ikisi ile de 7 tanesinin zararlı olduğu tespit edilmiştir ve sonuçlar Tablo 1'de verilmiştir. Yapılan literatür taramasına göre, bu çalışmada zararlı etkilerinin olabileceği tespit edilen 7 SNP ile ilgili yapılmış bir deneysel çalışmaya rastlanılmamıştır. 


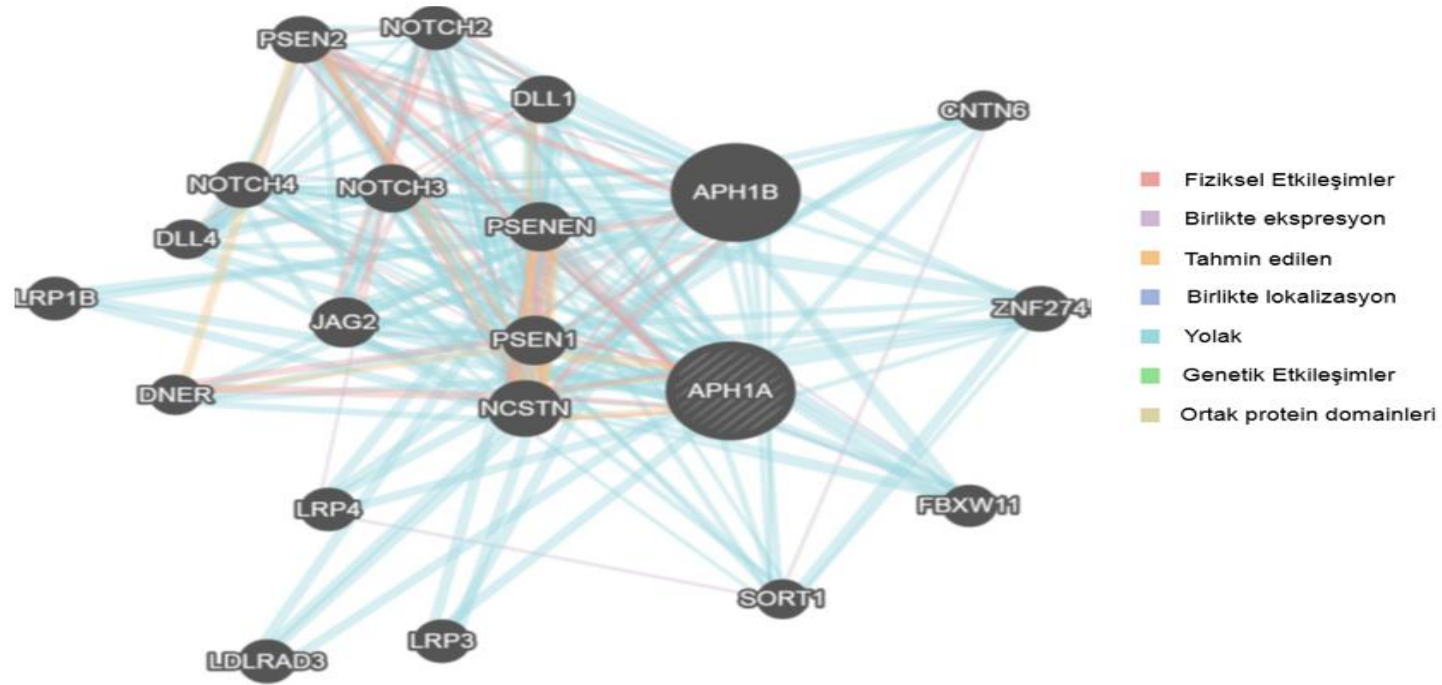

Şekil 2. APH1A gen-gen etkileşim ağı (http://genemania.org/).

Tablo 1. SIFT, PolyPhen-2 ve I-Mutant 2.0 yazılımlarının tahmin sonuçları

\begin{tabular}{|c|c|c|c|c|c|c|c|c|}
\hline \multirow{2}{*}{$\begin{array}{c}\text { SNP } \\
\text { NUMARASI }\end{array}$} & \multirow{2}{*}{$\begin{array}{l}\text { NÜKLEOTID } \\
\text { DEĞíşiMİ }\end{array}$} & \multirow{2}{*}{$\begin{array}{l}\text { AMINNO ASSiT } \\
\text { DEĞiş̧iMİ }\end{array}$} & \multirow{2}{*}{$\begin{array}{l}\text { POLYPHEN-2 } \\
\text { SONUCU }\end{array}$} & \multirow{2}{*}{$\begin{array}{l}\text { POLYPHEN-2 } \\
\text { SKORU }\end{array}$} & \multirow{2}{*}{$\begin{array}{c}\text { SIFT } \\
\text { SONUCU }\end{array}$} & \multirow{2}{*}{$\begin{array}{l}\text { SIFT } \\
\text { SKORU }\end{array}$} & \multicolumn{2}{|c|}{ I-MUTANT SONUCU } \\
\hline & & & & & & & $\begin{array}{l}\text { Güvenilirl } \\
\text { ik indeksi }\end{array}$ & Azalış/Artış \\
\hline rs11548266 & G/C (FWD) & T10S & $\begin{array}{l}\text { Muhtemel } \\
\text { Zararlı }\end{array}$ & 0.869 & Zararlı & 0.006 & 4 & Artış \\
\hline rs74126634 & C/G (FWD) & $\mathrm{C} 245 \mathrm{~W}$ & $\begin{array}{l}\text { Muhtemel } \\
\text { Zararlı }\end{array}$ & 1.000 & Zararlı & 0.005 & 2 & Artış \\
\hline rs145324799 & C/T (FWD) & V120A & $\begin{array}{l}\text { Muhtemel } \\
\text { Zararlı }\end{array}$ & 0.999 & Zararlı & 0.022 & 7 & Azalış \\
\hline rs199961673 & C/T (FWD) & $\mathrm{A} 13 \mathrm{~T}$ & $\begin{array}{l}\text { Muhtemel } \\
\text { Zararlı }\end{array}$ & 0.996 & Zararlı & 0.004 & 7 & Azalış \\
\hline rs370361277 & C/T (FWD) & Y90C & $\begin{array}{l}\text { Muhtemel } \\
\text { Zararlı }\end{array}$ & 1.000 & Zararlı & 0.004 & 1 & Artış \\
\hline rs370719475 & C/T (FWD) & $\mathrm{R} 260 \mathrm{C}$ & $\begin{array}{l}\text { Muhtemel } \\
\text { Zararlı }\end{array}$ & 0.981 & Zararlı & 0.006 & 6 & Azalış \\
\hline rs376071112 & C/T (FWD) & G233R & $\begin{array}{l}\text { Muhtemel } \\
\text { Zararlı }\end{array}$ & 1.000 & Zararlı & 0 & 7 & Azalış \\
\hline
\end{tabular}

PolyPhen-2 skoru $\geq 0.5$ ise muhtemel/olası zararl, SIFT skoru 0-1 arasında bir değer olup $\leq 0.05$ ise zararlıdır, $>0.05$ ise tolere edilebilir.

\subsection{I-Mutant 2.0 Yazılımı ile Amino Asit Değişimlerinin Protein Stabilizasyonuna Etkisi}

SIFT ve PolyPhen-2 yazılımları ile zararlı olduğu tespit edilen 7 SNP'nin protein stabilizasyonuna etkisi I-Mutant 2.0 yazılımı ile analiz edilmiştir. Sonuçlar incelendiğinde, bu SNP'lerden 3 tanesinin protein stabilizasyonunu arttırdığı, 4 tanesinin ise protein stabilizasyonunu azalttığı tespit edilmiştir ve sonuçlar Tablo 1'de verilmiștir .

\subsection{Project HOPE Yazılımı ile Amino Asit Değişimlerinin Modelleme Sonuçları}

Her bir amino asidin kendine özgü büyüklüğü, yükü ve hidrofobiklik değeri vardır. Bu değerler karşılaştırıldığında, orijinal yabanıl tip rezidü ile yeni eklenen mutant rezidünün çoğunlukla bu özellikler bakımından farklı olduğu gözlenmektedir. Tablo 2'de
APH1A genindeki zararlı SNP'lere ait modellemeler verilmiştir.

$\mathrm{Bu}$ çalışmada elde edilen APH1A genindeki zararlı SNP'lerin Project HOPE yazılımı ile belirlenen özellikleri Tablo 3'te verilmiştir.

\section{Tartışma ve Sonuç}

$\mathrm{Bu}$ çalışmada, SIFT, PolyPhen-2, I- Mutant 2.0 ve Project HOPE gibi bilgisayar tabanlı yazılım araçlarının kullanılmasına dayanan bir yaklaşım ile deneysel çalışmalar öncesinde APH1A genindeki hedef SNP'lerin belirlenmesi gerçekleştirilmiştir. Proteinin yapısı ve stabilizasyonuna zararlı etkisi olabilecek hedef SNP'lerin in silico olarak belirlenmesi genotipleme çalışmalarında oldukça önemlidir. Çalışmamızda, APH1A genindeki fonksiyonel etkisi olabilecek SNP'ler değerlendirilmiştir. 
Tablo 2. APH1A geninde yer alan zararlı SNP’lerin Project HOPE modelleme sonuçları

\begin{tabular}{|c|c|c|}
\hline SNP NO & Modelleme & Açıklama \\
\hline rs11548266 & 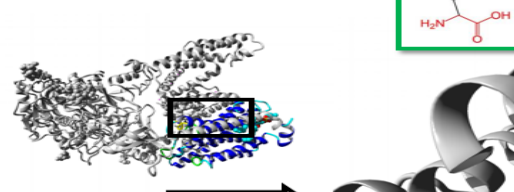 & $\begin{array}{l}\text { rs11548266 polimorfizminin } \\
\text { sebep olduğu } 10 \text {. pozisyondaki } \\
\text { treonin amino asidinin serine } \\
\text { dönüşümü }\end{array}$ \\
\hline rs74126634 & & $\begin{array}{l}\text { rs74126634 polimorfizminin } \\
\text { sebep olduğu 245. pozisyondaki } \\
\text { sistein amino a asidinin } \\
\text { triptofana dönüşümü }\end{array}$ \\
\hline rs145324799 & & $\begin{array}{l}\text { rs145324799 polimorfizminin } \\
\text { sebep olduğu } 120 \text {. pozisyondaki } \\
\text { valin amino asidinin alanine } \\
\text { dönüşümü }\end{array}$ \\
\hline rs199961673 & & $\begin{array}{l}\text { rs199961673 polimorfizminin } \\
\text { sebep olduğu 13. pozisyondaki } \\
\text { alanin amino asidinin treonine } \\
\text { dönüşümü }\end{array}$ \\
\hline rs370361277 & & $\begin{array}{l}\text { rs370361277 polimorfizminin } \\
\text { sebep olduğu } 90 \text {. pozisyondaki } \\
\text { tirozin amino asidinin sisteine } \\
\text { dönüşümü }\end{array}$ \\
\hline rs370719475 & & $\begin{array}{l}\text { rs370719475 polimorfizminin } \\
\text { sebep olduğu } 260 \text {. pozisyondaki } \\
\text { arjinin amino asidinin sisteine } \\
\text { dönüşümü }\end{array}$ \\
\hline rs376071112 & & $\begin{array}{l}\text { rs376071112 polimorfizminin } \\
\text { sebep olduğu } 233 \text {. pozisyondaki } \\
\text { glisin amino asidinin arjinine } \\
\text { dönüşümü }\end{array}$ \\
\hline Dolimorfizm & $\square$ Yabanıl rezidü $\square$ Mutant rezidū & \\
\hline
\end{tabular}


Tablo 3. Yabanıl ve mutant tip amino asitlerin Project HOPE yazılımına göre belirlenen özellikleri

\begin{tabular}{|c|c|c|c|c|c|c|c|}
\hline \multirow{2}{*}{ SNP NUMARASI } & \multirow{2}{*}{$\begin{array}{l}\text { AMİNOASİT } \\
\text { DEĞİŞIKLIÍĞİ }\end{array}$} & \multicolumn{3}{|c|}{ YABANIL TİP ÖZELLİKLERİ } & \multicolumn{3}{|c|}{ MUTANT TİP ÖZELLİKLERİ } \\
\hline & & Boyut & Yük & Hidrofobisiti & Boyut & Yük & Hidrofobisiti \\
\hline rs11548266 & $\mathrm{T} 10 \mathrm{~S}$ & $>$ & - & - & $<$ & - & - \\
\hline rs74126634 & $\mathrm{C} 245 \mathrm{~W}$ & $<$ & - & - & $>$ & - & - \\
\hline rs145324799 & V120A & $>$ & - & - & $<$ & - & - \\
\hline rs199961673 & $\mathrm{A} 13 \mathrm{~T}$ & $<$ & - & $>$ & $>$ & - & $<$ \\
\hline rs370361277 & Y90C & $>$ & - & $<$ & $<$ & - & $>$ \\
\hline rs370719475 & $\mathrm{R} 260 \mathrm{C}$ & $>$ & + yük & $<$ & $<$ & Nötr & $>$ \\
\hline rs376071112 & G233R & $<$ & Nötr & $>$ & $>$ & + yük & $<$ \\
\hline
\end{tabular}

APH1A genindeki toplam 3567 SNP'den 257'sinin amino asit değişimine sebep olduğu (yanlış anlamlı), bunlardan da rs11548266, rs74126634, rs145324799, rs199961673, rs370361277, rs370719475 ve rs376071112 polimorfizmlerinin zararlı olabileceği tespit edilmiștir.

APH1A proteninin amino asit diziliminde, SNP numarası rs11548266 olan polimorfizmin sebep olduğu amino asit değişimi, 10. pozisyondaki treonin amino asidinin serin amino asidine dönüşmesidir. Yabanıl ve mutant tip amino asit rezidüleri karşılaştırıldığında boyut olarak farklılık gösterdikleri ve mutant rezidünün yabanıldan daha küçük olduğu görülmektedir (Tablo 2 ve Tablo 3). Mutasyon sonucu 10. pozisyona serin amino asidinin eklenmesi proteinin çekirdeğinde boş bir alana sebep olacaktır. Ayrıca bu boyut farkı lipid-membran ile temasları etkileyebilecektir. 10. pozisyondaki rezidü, bir domainin çekirdeğine gömülü olarak yer alır. Yabanıl tip ve mutant rezidüler arasındaki farklar, bu domainin çekirdek yapısını bozabilir.

rs74126634 polimorfizminin sebep olduğu amino asit değişimi 245. pozisyondaki sistein amino asidinin triptofan amino asidine dönüşmesidir. Mutant rezidünün yabanıl tipten daha büyük olduğu Tablo 2 ve Tablo 3'de görülmektedir. Project HOPE yazılımının sonuçları, mutant rezidünün büyük olmasının bu bölgede çıkıntılara sebep olabileceğini göstermektedir. Yapısal bilginin elde edilememesi sebebiyle Project HOPE yazılımı polimorfizmin modellemelerine ait üç boyutlu görüntülerini oluşturamamıştır. $\mathrm{Bu}$ nedenle, Project HOPE, polimorfizm ile ilgili ek açıklamaları UniProt veritabanından, mutasyon analizi tahminlerini ise Reprof yazılımından kullanarak tespit etmiştir.

rs145324799 polimorfizminin sebep olduğu amino asit değişimi 120 . pozisyondaki valin amino asidinin alanin amino asidine dönüşmesidir. Mutant rezidünün yabanıl tipten daha küçük olduğu görülmektedir (Tablo 2 ve Tablo 3 ). Bu boyut farkı lipid membran ile teması etkileyebilmesinin yanı sıra oluşan mutasyon, protein çekirdeğinde boş bir alana sebep olabilecektir. Mutant rezidü bir ligand ile doğrudan temasa girmez. Bununla birlikte mutasyon, komşu rezidülerden biri aracılığıyla yapılan ligand temaslarını etkileyerek proteinin bölgesel stabilitesi üzerine etki gösterebilir. Ayrıca, bu rezidü, UniProt veritabanında bir transmembran domaini olarak açlklanmış bir bölgede bulunur ve bu domainin çekirdeğine gömülü olarak yer alır. Yabanıl tip ve mutant rezidü arasındaki farklar, bu domainin çekirdek yapısını bozabilir.

rs199961673 polimorfizminin sebep olduğu amino asit değişimi 13. pozisyondaki alanin amino asidinin treonin amino asidine dönüşmesidir. Yabanıl tip ve mutant amino asitlerin boyutları farklılı göstermektedir. Mutant rezidü ile yabanıl rezidü karşılaştırıldığında mutant rezidünün daha büyük olduğu belirlenmiştir (Tablo 2 ve Tablo 3 ). Bu boyut farklılıkları lipid-membran ile temasları etkileyebilir. Yabanıl tip rezidü proteinin çekirdeğine gömülü olarak yer alırken mutant rezidü daha büyük olması nedeniyle bu bölgeye muhtemelen yerleşemeyecektir. Yabanıl ve mutant tip rezidüler hidrofobiklik açısından da farklılık göstermektedir. Yabanıl tip, mutant rezidüden daha hidrofobiktir (Tablo 3). Hidrofobiklikteki bu farklıllklar, membran lipidleri ile hidrofobik etkileşimleri etkileyebilir. Bundan dolayı, mutasyon, proteinin çekirdeğinde hidrofobik etkileşimlerin kaybına neden olacaktır. 13. pozisyondaki rezidü, rs145324799 polimorfizminde olduğu gibi, UniProt veritabanında bir transmembran domaini olarak açıklanmış bir bölgede bulunur ve bu domainin çekirdeğine gömülü olarak yer alır. Yabanıl tip ve mutant rezidü arasındaki farklar, bu domainin çekirdek yapısını bozabilir.

rs370361277 polimorfizminin sebep olduğu amino asit değişimi 90. pozisyondaki tirozin amino asidinin sistein amino asidine dönüşmesidir. Yabanıl tip ve 
mutant amino asitlerin boyutları birbirinden farklıdır. Mutant rezidü, yabanıl tip rezidüden daha küçüktür (Tablo 2 ve Tablo 3). Bu durum, proteinin çekirdeğinde boş bir alana neden olacaktır. Yabanıl ve mutant tip rezidüler rs199961673 polimorfizminde olduğu gibi hidrofobiklik açısından da farklılık göstermektedir. Ancak rs199961673 polimorfizminden farklı olarak mutant rezidü yabanıl rezidüden daha hidrofobiktir (Tablo 3). Hidrofobiklikteki fark, hidrojen bağ etkileyebilecek bir faktördür. Yabanıl tip rezidü, 34. pozisyonda yer alan izolösin ile hidrojen bağ oluşturmaktadır. Yabanıl tip ve mutant rezidü arasındaki boyut farkı, mutant rezidünün yabanıl tip ile aynı hidrojen bağını yapmak için doğru konumda olmamasına neden olabilecektir. Sonuç olarak, proteinin çekirdeğinde hidrojen bağlarının kaybına neden olacak ve proteinin doğru katlanmasını bozacaktır. Ayrıca, 90. pozisyondaki rezidü bir domainin çekirdeğinde gömülü olarak yer alır. Yabanıl tip ve mutant rezidü arasındaki farklar, bu domainin çekirdek yapısını bozabilir.

rs370719475 polimorfizminin sebep olduğu amino asit değişimi 260. pozisyondaki arjinin amino asidinin sistein amino asidine dönüşmesidir (Tablo 2). Project HOPE yazılımı sonuçlarına göre, bu polimorfizm için rs74126634 polimorfizminde olduğu gibi üç boyutlu yapı veya modelleme şablonu bulunamamıştır. $\mathrm{Bu}$ nedenle, Project HOPE, polimorfizm ile ilgili ek açılamaları UniProt veritabanından, mutasyon analizi tahminlerini ise Reprof yazılımından kullanarak tespit etmiştir. Sonuçlar incelendiğinde, yabanıl tip ve mutant amino asitlerin boyutlarının farklılı gösterdiği görülmektedir. Mutant rezidü yabanıl tip rezidüden daha küçüktür (Tablo 2 ve Tablo 3). Mutant rezidünün küçük olması etkileşimlerin kaybına sebep olabilecektir. Bunun yanı sıra, yabanıl tip ve mutant tip rezidülerin yükleri de farklılık göstermektedir. Yabanıl tip rezidü pozitif yüklüyken, mutant rezidünün yükü nötrdür (Tablo 3). Yabanıl tipin yükü mutant rezidüde kaybolacağı için bu durum diğer moleküllerle veya rezidülerle etkileşimlerin de kaybına neden olabilecektir. Yabanıl ve mutant tip rezidüler rs199961673 ve rs370361277 polimorfizmlerinde olduğu gibi hidrofobiklik açısından da farklılık göstermektedir. rs370361277 polimorfizminde olduğu gibi rs370719475 polimorfizminde de mutant rezidü yabanıl rezidüden daha hidrofobiktir (Tablo 3). Bu durum, hidrojen bağlarının kaybıyla sonuçlanabilir ve/veya doğru katlanmayı bozabilir.

rs376071112 polimorfizminin sebep olduğu amino asit değişimi 233. pozisyondaki glisin amino asidinin arjinin amino asidine dönüşmesidir. Çalışmamızda elde edilen Project HOPE sonuçlarına göre, yabanıl ve mutant tip amino asitler arasında boyut farklılığ vardır. Mutant rezidünün yabanıl tip rezidüden daha büyük olduğu belirlenmiştir (Tablo 2 ve Tablo 3). Bu boyut farklılıkları lipid membran ile temasları etkileyebilmektedir. 233. pozisyonda yer alan rezidü proteinin yüzeyinde bulunur ve bu rezidünün mutasyonu diğer moleküllerle veya proteinin diğer kısımlarıyla etkileşimleri bozabilir. $\mathrm{Bu}$ rezidünün kıvrılma açısı sıra dışıdır (Tablo 2). Yabanıl tip rezidü glisin, diğer tüm rezidülerden daha esnektir. Sadece glisin bu kıvrılma açılarını yapmak için yeterince esnek bir amino asittir. Bu esneklik proteinin işlevi için gerekli olabilmektedir. Glisinin mutasyonu proteinin bu işlevini ortadan kaldırabilmektedir. $\mathrm{Bu}$ rezidünün farklı bir rezidüye mutasyonu, lokal iskeleti yanlıș bir konformasyona zorlayacak ve lokal yapısını bozacaktır. rs370719475 polimorfizminde olduğu gibi, rs376071112 polimorfizminde de yabanıl tip ve mutant tip rezidülerin yükleri de farklılık göstermektedir. Ancak rs370719475 polimorfizminden farklı olarak, yabanıl tip rezidü nötr, mutant tip rezidü ise pozitif yüklüdür (Tablo 3 ). rs145324799 polimorfizminde olduğu gibi, rs376071112 polimorfizminde de mutant rezidü bir ligand ile doğrudan temasa girmez. Mutant rezidü komşu rezidülerden biri aracılığıyla yapılan ligand temaslarını etkileyerek proteinin bölgesel stabilitesi üzerine etki gösterebilir. Yabanıl ve mutant tip rezidüler rs199961673, rs370361277 ve rs370719475 polimorfizmlerinde olduğu gibi hidrofobiklik açısından da farklılık göstermektedir. Yabanıl tip rezidü rs199961673 polimorfizminde olduğu gibi mutant rezidüden daha hidrofobiktir (Tablo 3). Hidrofobiklikte meydana gelen bu farklılıklar, membran lipidleri ile hidrofobik etkileşimleri etkileyebilmektedir. Ayrıca, 233. pozisyondaki rezidü, rs145324799 ve rs199961673 polimorfizmlerinde olduğu gibi, UniProt veritabanında bir transmembran domaini olarak açıklanmış bir bölgede bulunur. Mutasyona uğramış rezidü fonksiyonu bilinmeyen bir domainin yüzeyinde yer alır. Bilinen domainler incelendiğinde teması bulunmamıștır. Fakat bilinmeyen diğer domain ya da moleküller ile teması olasıdır. Böyle bir temas olması durumunda mutasyondan etkilenecektir.

GeneMANIA yazılımından elde edilen gen-gen etkileşim sonuçları, APH1A geninin en fazla etkileşimde olduğu genlerin sırası ile APH1B, NCSTN, JAG2, PSEN1 ve PSENEN olduğunu göstermiştir. Bunlardan APH1B, NCSTN, PSEN1 ve PSENEN genleri Alzheimer hastalığı ile ilişkilendirilen $\gamma$-sekretaz kompleksinde yer almaktadır. JAG2 (jagged canonical Notch ligand 2) geni ise Notch sinyal yolağında yer almaktadır (https://www.ncbi.nlm.nih.gov/gene). Notch sinyal yolağı, hücre farklılaşması, proliferasyonu, sağkalımı ve apoptozis için anahtar rol oynamaktadır [27].

Amino asit sübstitüsyonlarının protein yapısı ve fonksiyonu üzerindeki etkilerini ortaya çlkarmak, tek amino asit mutasyonlarının neden olduğu insan hastalıklarının karmaşık mekanizmalarını anlamak 
için kritik öneme sahiptir [28,29]. Bir protein içindeki kilit alanlarda meydana gelen amino asit değişiklikleri, tuz köprülerinin kırılması, etkileşim ağının değiștirilmesi, hidrojen bağlarının bozulmasına neden olmayı da içeren bir dizi konformasyon değişikliği ile sonuçlanabilmektedir. $\mathrm{Bu}$ değişiklikler, proteinin enerji düzeyinin bozulmasına, proteinin katlanma kinetiğinin etkilenmesine, proteinin kümeleşmesine ve proteinin stabilizasyonunun bozulmasına neden olabilmektedir $[29,30]$. Protein stabilitesi değişikliğinin hastalıklara sebep olan ortak bir mekanizma olduğu ve özellikle tek gen hastalıklarının çoğunda amino asit sübstitüsyonlarına sebep olan tek mutasyonların sorumlu olduğu bilinmektedir [29,31].

Çalışmamızda elde edilen sonuçların APH1A geni ile ilgili yapılacak olan genotipleme araştırmalarına, SNP seçimi ve deney tasarımı aşamalarında katkı sağlayacağı tahmin edilmektedir. Literatür incelendiğinde genlerdeki SNP'lerin in silico analizlerine ait tahmin çalışmalarının kısıtlığı olduğu ve bu sebeple, ileride gerek deneysel gerekse in silico çalışmaların yapılması gerektiği düşünülmektedir.

\section{Kaynakça}

[1] El Halawany AM, Sayed NSE, Abdallah HM, El Dine RS. 2017. Protective effects of gingerol on streptozotocin-induced sporadic Alzheimer's disease: emphasis on inhibition of $\beta$-amyloid, COX-2, alpha-, beta-secretases and APH1a. Scientific Reports. 7(1):2902.

[2] Iqbal K, Grundke-Iqbal I. 2010. Alzheimer's disease, a multifactorial disorder seeking multitherapies. Alzheimer's \& Dementia: Elsevier; 420-424.

[3] Yonemura Y, Futai E, Yagishita S, Kaether C, Ishiura S. 2016. Specific combinations of presenilins and Aph1s affect the substrate specificity and activity of $\gamma$-secretase. Biochemical and biophysical research communications.478(4):1751-1757.

[4] De Strooper B. 2003. Aph-1, Pen-2, and nicastrin with presenilin generate an active $\gamma$-secretase complex. Neuron. 38(1):9-12.

[5] Gertsik N, Chiu D, LI Y. 2015. Complex regulation of gamma-secretase: from obligatory to modulatory subunits. Frontiers in aging neuroscience. 6:342.

[6] Hur J-Y, Gertsik N, Johnson D, Li Y-M. 2016. $\gamma$ Secretase Inhibitors: From Chemical Probes to Drug Development. Developing Therapeutics for Alzheimer's Disease: Elsevier; 63-76.

[7] Lee S-F, Shah S, Li H, Yu C, Han W, Yu G. 2002. Mammalian APH-1 interacts with presenilin and nicastrin and is required for intramembrane proteolysis of amyloid- $\beta$ precursor protein and
Notch. Journal of Biological Chemistry. 277(47):45013-45019.

[8] Takasugi N, Tomita T, Hayashi I, et al. 2003. The role of presenilin cofactors in the $\gamma$-secretase complex. Nature. 422(6930):438.

[9] Haapasalo A, Kovacs DM. 2011. The many substrates of presenilin $/ \gamma$-secretase. Journal of Alzheimer's disease.25(1):3-28.

[10] Mohandas E, Rajmohan V, Raghunath B. 2009. Neurobiology of Alzheimer's disease. Indian journal of psychiatry. 51(1):55

[11] Hemming ML, Selkoe DJ. 2005. Amyloid $\beta$ protein is degraded by cellular angiotensinconverting enzyme (ACE) and elevated by an ACE inhibitor. Journal of Biological Chemistry. 280(45):37644-37650.

[12] Zhang Y, McLaughlin R, Goodyer C, LeBlanc A. 2002. Selective cytotoxicity of intracellular amyloid $\beta$ peptide1-42 through p53 and Bax in cultured primary human neurons. The Journal of cell biology. 156(3):519-529.

[13] Özkay ÜD, Öztürk Y, Can ÖD. 2011. Yaşlanan dünyanın hastalığı: Alzheimer hastalığı. SDÜ Tıp Fakültesi Dergisi.18(1):35-42.

[14] Reddy PH, Beal MF. 2008. Amyloid beta, mitochondrial dysfunction and synaptic damage: implications for cognitive decline in aging and Alzheimer's disease. Trends in molecular medicine.14(2):45-53.

[15] Harley, I. and S. Narod, 2009. Single nucleotide polymorphisms-variation on a theme. BJOG: An International Journal of Obstetrics \& Gynaecology, 116(12): p. 1556-1557.

[16] Ozkan, E., et al., 2015. Genotyping and analysis of rs7501939 polymorphism for prostate cancer. Sigma journal of engineering and natural sciences-Sigma mühendislik ve fen bilimleri dergisi, 6(1): p. 101-107.

[17] Poli M, Gatta LB, Archetti S, Padovani A, Albertini A, Finazzi D. 2003. Association analysis between anterior-pharynx defective-1 genes polymorphisms and Alzheimer's disease. Neuroscience letters. 350(2):77-80.

[18] Wang Y, Jia J. 2009. Association between promoter polymorphisms in anterior pharynxdefective-1a and sporadic Alzheimer's disease in the North Chinese Han population. Neuroscience letters. 455(2):101-104.

[19] Qin W, Jia L, Zhou A, et al. 2011. The- 980C/G polymorphism in APH-1A promoter confers risk of Alzheimer's disease. Aging cell.10(4):711-719.

[20] Yu H, Zhang H, Yang Y, Li W, Yang G, Lü L. 2015. Association of gene polymorphisms with the susceptibility of schizophrenia in Han Chinese 
population. Zhonghua yi xue za zhi. 95(47):3803-3807.

[21] Çinleti BA, Yardımcı N, Aytürk Z, et al. 2015. The effects and interactions of APOE and APH-1A polymorphisms in Alzheimer disease. Turkish journal of medical sciences. 45(5):1098-1105.

[22] Marwa Mohamed Osman, Ahmed Sidahmed Khalifa, Alaa Eldin Yousri Mutasim, et al. 2016. In silico Analysis of Single Nucleotide Polymorphisms (Snps) in Human FTO Gene. JSM Bioinformatics, Genomics and Proteomics.

[23] Ng PC, Henikoff S. 2006. Predicting the effects of amino acid substitutions on protein function. Annu. Rev. Genomics Hum. Genet.7:61-80.

[24] Kaur T, Thakur K, Singh J, Kamboj SS, Kaur M. 2017. Identification of functional SNPs in human LGALS3 gene by in silico analyses. Egyptian Journal of Medical Human Genetics. 18(4):321328.

[25] Adzhubei IA, Schmidt S, Peshkin L, et al. 2010. A method and server for predicting damaging missense mutations. Nature methods.7(4):248.

[26] Capriotti E, Calabrese R, Casadio R. 2006.
Predicting the insurgence of human genetic diseases associated to single point protein mutations with support vector machines and evolutionary information. Bioinformatics. 22(22):2729-2734.

[27] Ye, Q.-F., et al., 2012. Silencing Notch-1 induces apoptosis and increases the chemosensitivity of prostate cancer cells to docetaxel through Bcl-2 and Bax. Oncology letters, 3(4): p. 879-884.

[28] Cargill M, Altshuler D, Ireland J, et al. 1999. Characterization of single-nucleotide polymorphisms in coding regions of human genes. Nature genetics. 22(3):231.

[29] Teng S, Wang L, Srivastava AK, Schwartz CE, Alexov E. 2010. Structural assessment of the effects of amino acid substitutions on protein stability and protein-protein interaction. International journal of computational biology and drug design. 3(4):334.

[30] Dill KA, Fiebig KM, Chan HS. 1993. Cooperativity in protein-folding kinetics. Proceedings of the National Academy of Sciences. 90(5):1942-1946.

[31] Wang Z, Moult J. 2001. SNPs, protein structure, and disease. Human mutation. 17(4):263-270. 